\title{
Immune-mediated cytotoxicity in inflammatory bowel disease
}

\author{
Stephan R TARgan, MD, Richard L DeEm, MS, Fergus Shanahan, MD
}

\begin{abstract}
Thirty years of research on the role of immune-mediated cytotoxic activity in the tissue injury of inflammatory bowel disease (IBD) has yielded only inconclusive data on the relevance of cytotoxic mechanisms. Two hypotheses have been advanced. One is that the destruction of target cells is mediated by direct recognition of target antigens by cytotoxic cells which in turn triggers lysis. Another hypothesis is that lysis occurs via an indirect bystander mechanism in which cells do not recognize a specific antigen on the target, but upon nonspecific activation release cytokines which are capable of lysing the target. The authors have investigated both hypotheses and studied the role of cytotoxic $T$ cells and cytotoxic factors released from activated $\mathrm{T}$ cells in the destruction of epithelial cells. Elevated levels of cytotoxic T cells were found in peripheral blood lymphocytes of patients with IBD, particularly Crohn's disease. The cytotoxic T cells were contained within the Leu $7+, C D 8+T$ cell subset and were detected using anti-CD3-triggered lysis. Increased cytotoxic $\mathrm{T}$ cell activity was also present within inflamed mucosa of patients with both Crohn's disease and ulcerative colitis. The specific targets of this activity have yet to be determined. Activation of mucosal T cells by antibodies to the T cell receptor (anti-CD3) in organ culture of normal fetal jejunum induces an enteropathy characterized by villous atrophy and crypt cell hyperplasia. This same change is seen near aphthous ulcers in patients with Crohn's disease. Soluble cytokines produced by T cells might be responsible for the mucosal damage observed in these two models of mucosal injury. The goal of this study was to establish in vitro if cytotoxic cytokines can be released by triggering isolated colonic $T$ cells, and what cytokine interactions are required for killing of colonic epithelial cells. These results demonstrate that human lamina propria lymphocyte T cells, triggered by addition of anti-CD3 and target cells, produce tumour necrosis factor-alpha and interferon-gamma, both of which are required for optimal killing of HT-29. Simultaneous release of these cytokines in the vicinity of epithelial cells during immune responses could play an important role in mucosal damage in IBD. The development of animal models and long term cultures of epithelial cells will allow many advances in research of the role of immune-mediated cytotoxicity in IBD. Can J Gastroenterol 1990;4(7):278-284 (pour résumé, voir page 279)
\end{abstract}

Key Words: Cytotoxicity, Etiology, Immunology, Inflammatory bowel disease

University of California-Los Angeles School of Medicine, Division of Gastroenterology, Los Angeles, California, USA

Correspondence and reprints: Dr Stephan R Targan, UCLA School of Medicine, Division of Gastroenterology, 900 Veteran Avenue, Los Angeles, CA 90024, USA. Telephone (213)

206-3580
$T$ HE UNDERLYING EVENTS THAT trigger or perpetuate mucosal damage in Crohn's disease and ulcerative colitis have not been defined. As yet, the target of the immune attack has not been determined, although the epithelial cell is thought to be the likely candidate. The role of immune cytotoxic mechanisms in epithelial injury has been a focus of investigation for almost 30 years. Two pathways of immune-mediated killing have been proposed. The direct pathway depicted in Figure 1, or 'autoimmune' damage, is based on the recognition of a select antigen on the target tissue by any of several effector mechanisms within the immune system. The mechanism of target killing could be either complementmediated lysis or antigen-triggered lysis. Cells could recognize antigens in conjunction with major histocompatibility antigens, such as cytotoxic $\mathrm{T}$ cells, or through direct antigen recognition by a variety of effector cell types, ie, T cells, natural killer cells, killer cells which become functional only after exposure to interleukin-2, or lymphokine-activated killer cells.

A second pathway, also known as the 'innocent bystander' attack is illustrated in Figure 2. This pathway is based on a defect in immunoregulation allowing a cascade of uncontrolled immunologic events. There is no specific recognition of antigen on a target cell, but the release of 'cytotoxic' soluble 


\section{Cytotoxicité anticorps dépendante dans les maladies inflammatoires de l'intestin}

RESUME: Trente années de recherche consacrées au rôle de l'activité cytotoxique anticorps dépendante dans les lésions de la muqueuse caractéristiques des maladies inflammatoires de l'intestin (MII) n'ont fourni que des données peu concluantes sur la pertinence des mécanismes cytotoxiques. Deux hypothèses ont été proposées: que la destruction des cellules cibles est provoquée par la reconnaissance directe des antigènes cibles par les cellules cytotoxiques qui déclenchent à leur tour la lyse; et que la lyse survient par le biais d'un mécanisme indirect où les cellules ne reconnaissent pas d'antigène spécifique mais, après activation non spécifique, libèrent les cytokines en mesure de lyser la cible. Les auteurs ont étudié les deux hypothèses et examiné le rôle des cellules T cytotoxiques et des facteurs cytotoxiques excrétés par les cellules $T$ activées lors de la destruction des cellules épithéliales. Ils ont noté des concentrations élevées de cellules $\mathrm{T}$ cytotoxiques dans les lymphocytes du sang périphérique des patients porteurs de MII et de maladie de Crohn surtout. Les cellules T cytotoxiques se trouvaient dans le sous-groupe de cellules T: Leu 7+ et CD8+, et ont été détectées utilisant la lyse déclenchée par l'anti-CD3. L'activité accrue des cellules T cytotoxiques était également présente au sein de la muqueuse des patients porteurs de maladie de Crohn et de colite ulcéreuse. Les cibles spécifiques de cette activité sont à déterminer. L'activation des cellules $T$ de la muqueuse par les anticorps et envers le récepteur de la cellule $\mathrm{T}$ (anti-CD3) dans la culture d'organe provenant de jejénum foetal normal provoque une entéropathie caractérisée par une atrophie villeuse et une hyperplasie des cellules cryptiques. Cette même modification est visible près des ulcères aphteux chez les patients atteints de maladie de Crohn. Les cytokines solubles provenant des cellules $\mathrm{T}$ pourraient être responsables des lésions observées dans les deux modèles étudiés. L'étude visait à déterminer in vitro si l'activation des cellules T coliques peut entraîner la libération des cytokines cytotoxiques et quelles sont les interactions des cytokines nécessaires à la destruction des cellules épithéliales coliques. Selon les résultats, les cellules T humaines, activées par l'ajout d'anti-CD3 et de cellules cibles, libèrent le facteur de nécrose tumorale alpha et l'interféron-gamma, tous deux nécessaires pour la destruction optimale du HT-29. La libération simultanée de ces deux cytokines à proximité des cellules épithéliales au cours des réponses immunitaires pourrait jouer un rôle important dans les lésions muqueuses des MII. L'élaboration de modèles animaux et de cultures à long terme des cellules épithéliales contribuera aux nombreux progrès des recherches portant sur le rôle de la cytotoxicité anticorps-dépendante dans les MII.

factors from cells. T cells reaching to multiple or select antigens in an uncontrolled fashion in the vicinity of the epithelial cell could cause lysis of such targets directly, as well as recruitment of other cell types and secretion of other factors.

Several investigators have reported lymphocyte-mediated cytotoxicity against epithelial cells in both Crohn's disease and ulcerative colitis (1-11). Lymphocyte-mediated cytotoxicity has been shown using peripheral blood lymphocytes and intestinal mononuclear cells. Antibody-dependent cellular cytotoxicity, in which lymphocytes are triggered by antibody directed against an antigen on epithelial cells, is the apparent mechanism $(3-8,11)$. The cytotoxic reaction occurs only with colonic, and not small bowel, epithelial cells - even in patients with Crohn's disease limited to the small intestine. Therefore, not all lesions of Crohn's disease can be characterized by this example. Interpretation of these findings is complicated due to potential limitations of some of the experiments, as freshly isolated epithelial cells are labile and unreliable as target cells (12). When cells are isolated from inflamed tissue, the problem may be compounded and comparisons inherently biased.

Erythrocytes coated with epithelial antigens have also been used to study epithelial autosensitization (13-14). When injected with adjuvant, soluble epithelial cell antigen complexes isolated from rat and murine colon and intestine induced organ-specific inflammation (15). These antigens, bound to indicator cells (chicken erythrocytes), were found to be lysed by peripheral blood and lamina propria lymphocytes from patients with Crohn's disease and ulcerative colitis, but not in samples from control subjects (13). Erythrocytes labelled with purified kidney epithelial antigens were resistant to lysis; therefore, the cytotoxic reaction was specific for gutassociated epithelial antigens. Direct T cell cytotoxicity appeared to be involved when intestinal lamina propria lymphocytes were tested, although the mechanism of lysis was antibody-dependent cellular cytotoxicity when peripheral blood lymphocytes were the effector cells (13). The low levels of lysis observed, the unusual cytotoxicity curve, and the requirement in classical cytotoxic $\mathrm{T}$ cell killing that the target antigen be presented to the effector cell in association with the major histocompatibility complex (MHC) $(16,17)$ render the significance of these findings uncertain; reactions against epithelial antigens on the surface of chicken erythrocytes cannot be MHC. restricted. Several studies have highlighted antibody-dependent cellular cytotoxicity $(8,11,12)$, yet whether isolated intestinal mononuclear cells can mediate this cytotoxicity is controversial (18-22). The influence of enzymatic isolation procedures on lymphocyte and Fc receptor function might account for the difference in results (23-25).

Certain tumour and virally infected cells appear to be targets of natural killer cell cytotoxic activity. The peripheral blood of patients with Crohn's disease and ulcerative colitis has been shown to have decreased natural killer cell function, probably secondary to the inflammatory process $(26-28)$. (It is known that plasma from the mesenteric vein of patients with intestinal inflammation inhibits natural killer cells [29].) Because of the low numbers and low levels of activity in unfractionated cell preparations from normal or inflamed intestines, 


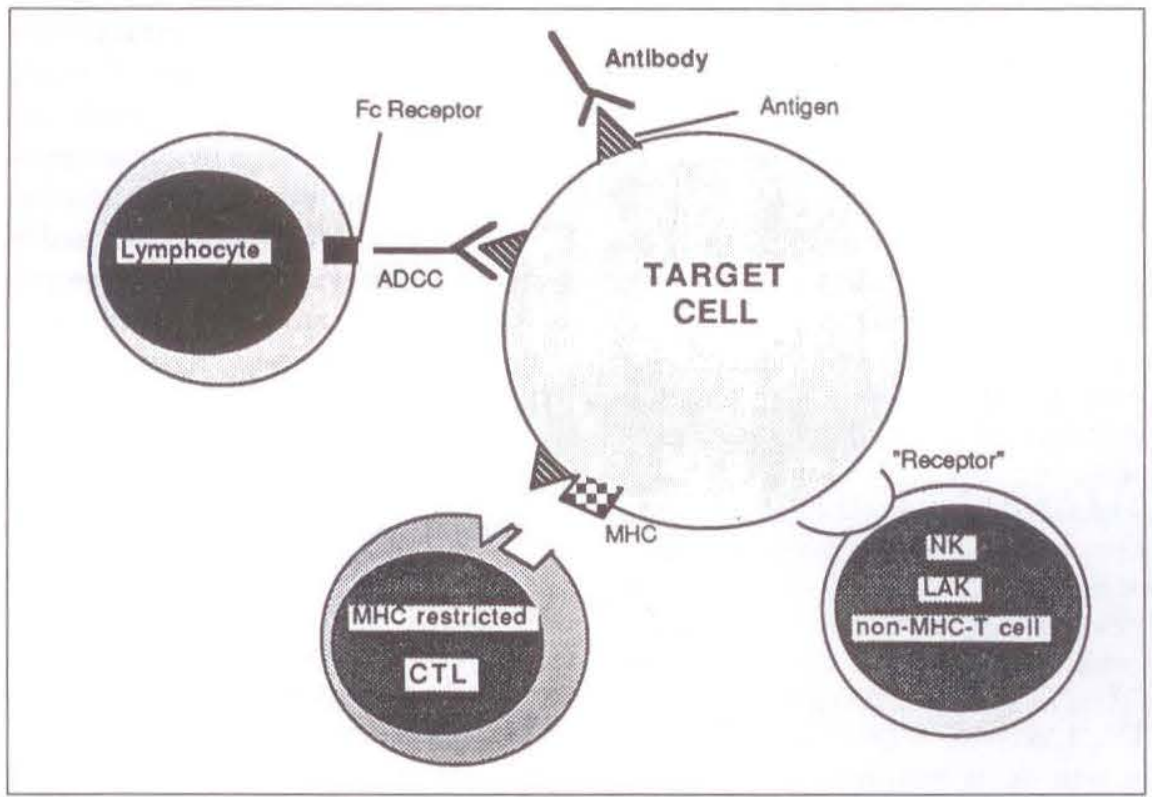

Figure 1) Mucosal immune effector mechanisms that have been proposed as possible mediators of a direct specific attack against the putative target cell in inflammatory bowel disease. These might be generated either in response to an alteration in the target cell, to an external agent, or to a breakdoun in mucosal immune tolerance to normal host epithelial cells. ADCC Antibody-dependent cellular cytotoxicity; MHC Major histocompatibility complex; CTL Cytotoxic T lymphocyte; NK Natural killer cell; LAK Lymphocyte activated killer cell

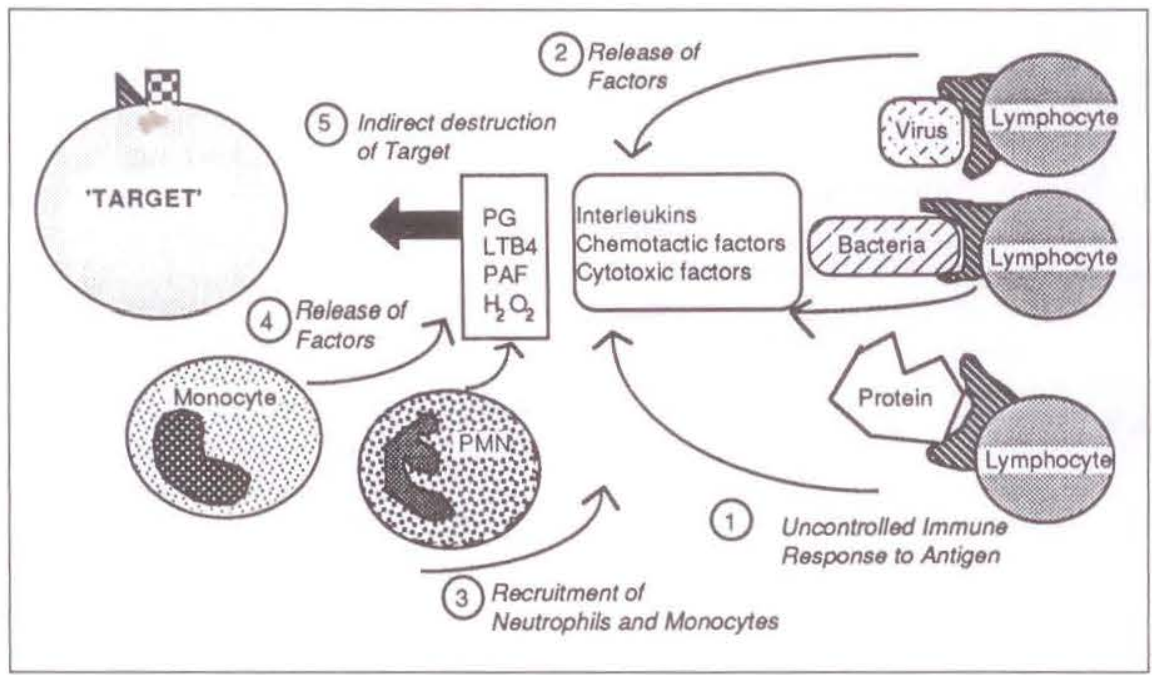

Figure 2) Tissue damage via a nonspecific indirect or 'innocent bystander' attack. A disorder of mucosal immune regulation leads to uncontrolled overreactivity to a variety of exogenous antigens. The increased proliferation of lymphocytes with release of cytokines results in recruitment of additional inflammatory mediators such as prostaglandins (PG) and leukotrienes (LTB 4 ) into the mucosa amplifies the inflammatory response and leads to local tissue damage. PAF Platelet-activating factor; PMN Polymorphonuclear leukocytes

studies of mucosal natural killer cells in patients with inflammatory bowel disease (IBD) are difficult to interpret (2123,30-34). Therefore, direct natural killer cytolytic effects are not thought to be important in intestinal disease (35). Dismissal of natural killer cells on a numerical basis, however, may be in- appropriate, because the number of cells required for effective tumour and viral infection surveillance and immunoregulation in vivo is not known (36).

Human mucosal lymphocytes and peripheral blood lymphocytes cultured in the presence of interleukin- 2 induce lymphokine-activated killer cells (30, $31,37)$. Since these cells have lytic activity against both natural killer-sensitive and natural killer-resistant target cells, they are currently under intense investigation for potential use in the treatment of metastatic cancer, includ. ing colorectal cancer (38). The precursors of the mucosal lymphokine-ac. tivated killer phenomenon are CD16 $(30,31)$, unlike the peripheral blood, where the majority of lymphokine-ac. tivated killer cells are generated from natural killer cells that are $\mathrm{CD} 16^{+}(39$, $40)$. The generation of mucosal lym. phokine-activated killer cell activity by exogenously administered interleukin. 2 is normal in $\operatorname{IBD}(30,41)$. The production of interleukin-2 by mononuclear cells from these patients, however, is significantly diminished under certain conditions in vitro (42). It is possible that defective generation of mucosal lymphokine-activated killer cells due to reduced production of in. terleukin-2 locally might contribute to the increased frequency of intestinal cancer in patients with longstanding IBD, although the role of lymphokineactivated killers as a defence mechanism in vivo is not known.

Little is known of cytotoxic T lym. phocyte function in either the normal human mucosa or in the mucosa of patients with IBD. T cell cytotoxicity has been measured by mitogen-induced cellular cytotoxicity in culture. A decrease in $\mathrm{T}$ cell cytotoxicity in the mucosa of patients with IBD has been reported $(21,32,43)$. The nonspecific cytotoxicity induced by mitogens, how. ever, is probably distinct from that of specifically in vivo-activated killer cells $(31,44)$. It is possible that a subset of in vivo-activated cytotoxic T lymphocytes (possibly reactive to self antigens) might coexist with depressed (probably secondary to the disease) nonspecific $T$ cytolytic function.

It may still be possible to examine indirectly cytotoxic $\mathrm{T}$ cells even though the antigens responsible for immune reactivity in IBD are not known. Two functional components, one responsible for antigen recognition and the other (CD3) responsible for signal transduction, comprise the human $T$ 
cell antigen receptor $(17,45)$. Subsequent stimulation in vitro with monoclonal antibodies to the CD3 component of this receptor will trigger the cytolytic activity of the cell, if a cytotoxic $\mathrm{T}$ cell has already been primed by antigen in vivo. Therefore, this technique might be a useful indirect method for measuring and identifying in vivo-primed cytotoxic $\mathrm{T}$ lymphocytes when the antigen to which they are reacting is not known (46). Using this method, the author has recently demonstrated the lytic function of freshly isolated cytotoxic T lymphocytes from uninflamed intestinal mucosa (47). He has shown that antiCD3-triggered peripheral blood lymphocytes have greater cytotoxic activity in patients with IBD than in normal subjects (48). The author has recently demonstrated that such cytotoxic $\mathrm{T}$ cell activity is also increased in the mucosa of patients with Crohn's disease and in many intestinal samples from patients with ulcerative colitis (49). The clonality of these cytotoxic T cells, as well as the targets against which they are directed, are currently under investigation.

The innocent bystander hypothesis implies the existence of some defect in the regulation of mucosal immunity leading to an uncontrolled response to a variety of exogenous antigens (virus, bacteria or protein). Such an event would lead to the generation of effector cells within the efferent mucosal compartment or lamina propria, leading to release of cytokines and chemotactic factors and resulting in the recruitment of acute inflammatory cells (ie, neutrophils, eosinophils and mast cells). The arrival of these auxiliary effectors is associated with release of various additional mediators such as arachidonate metabolites and oxygen radicals which, in conjunction with cytokines, are locally injurious in a nonspecific fashion. This model hypothesizes a central role for cytokines in orchestrating epithelial damage.

Lymphocytes in the lamina propria halve been shown to be different from lymphocytes in the peripheral blood in regard to phenotype (47) and level of activation (50). Since these lamina propria cells are constantly exposed to foreign antigens, it is important that response to challenge be thorough and yet restricted enough so that normal tissue is not damaged during an immune response. When this response becomes uncontrolled, mucosal damage occurs, such as that seen in IBD (12), celiac disease (51) and other inflammatory diseases of the intestine. A series of recent observations provides support for the central role of $\mathrm{T}$ cells and associated cytokines in nonspecific injury to epithelial cells as a possible mechanism of tissue injury in IBD. Organ culture studies of human fetal jejunum have elegantly shown that $T$ cell activation using monoclonal antibodies to the CD3 component of the T cell receptor led to a marked enteropathy consisting of villous atrophy and crypt cell hyperplasia (52). Villous atrophy and crypt cell hyperplasia were also demonstrated in the mucosa adjacent to aphthous ulcerations in Crohn's disease (53).

Many different cytokines are produced by various immunocytes during an immune response. These cytokines not only react with other cells of the immune system, but also affect the functions of nonimmune cell types, such as epithelial cells $(54,55)$. It has been demonstrated that there is increased MHC class II expression on epithelial cells overlying inflamed areas in IBD tissue samples (54). It has also been demonstrated in vitro that recombinant cytokines, interferon-gamma and tumour necrosis factor (TNF). alpha can induce such expression $(54,55)$.

The author has recently performed studies to examine how increased numbers of 'activated' mucosal $\mathrm{T}$ cells might contribute to damage, and whether such cytokines play a role. Mucosal $\mathrm{T}$ cells were polyclonally activated by incubation with anti-CD3 monoclonal antibody in combination with crosslinking via an $F_{c}$ receptor-expressing target cell (K562). This treatment resulted in secretion of cytokines that were cytostatic to the human epithelial colon line HT-29. Subsequent experiments demonstrated that these supernatants were also cytotoxic to the murine fibroblast line, L929 and HT-29. Little or no spontaneous secretion of these cytokines occurred and incubation of lamina propria lymphocytes with anti-CD3 alone resulted in less secretion of cytotoxic/cytostatic cytokines compared to incubation with anti-CD3 and K562 targets. These results suggest that crosslinking of the CD3 receptor is probably required for optimal triggering of cytokine release.

Specific anticytokine monoclonal antibodies were used to determine what cytokines were produced by the triggered lamina propria lymphocytes. TNF-beta, which one might expect to be produced by cytotoxic $\mathrm{T}$ cells, is either present in low quantities or not at all, as shown by the inability of antiTNF-beta to neutralize supernatant cytotoxicity against L929. However, either anti-TNF-alpha or anti-interferon-gamma inhibited HF-29 cytotoxicity induced by lamina propria lymphocyte supernatants, demonstrating that both cytokines were secreted by the lamina propria lymphocytes, and both were required for optimal killing of HT-29. Further evidence was seen in experiments using recombinant TNFalpha and interferon-gamma, which also demonstrated that both cytokines were required for optimal killing of HT. 29.

TNF-alpha and interferon-gamma have been shown to be capable effector molecules in immune destruction of self tissues (56-58). Individually or in combination, TNF-alpha and interferon-gamma destroyed isolated betaislet cells in vitro (58). In addition, TNF-alpha has been identified in lesions from brain tissues of multiple sclerosis patients (59). Normal colonic epithelial cells may or may not have the same sensitivity to these cytokines as colonic cell lines. The ability of interferon-gamma to up-regulate a variety of cellular receptors including those for TNF-alpha suggests one mechanism responsible for synergism between these two cytokines (60). Sensitivity of targets to TNF-alpha or interferongamma may be related to expression of certain antigens or receptors on their cell surfaces or effects of viral products 
(1) More Senstive to Triggering

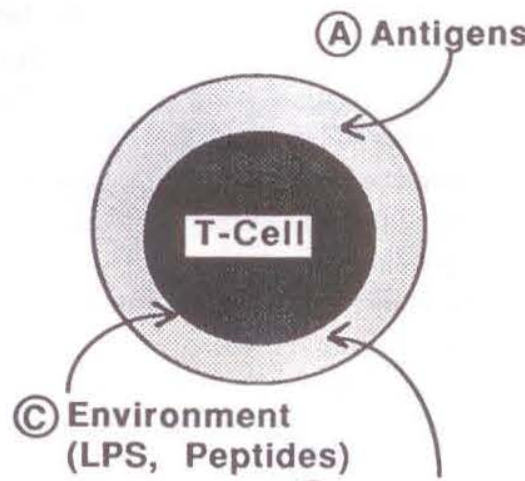

(B) Mitogens
(2) Less Sensitive to Down Regulatory Signals

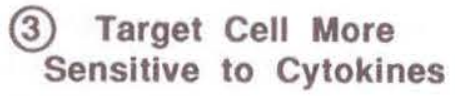

(A) Cytokines

(IL-4, TGF-B, IL-?)

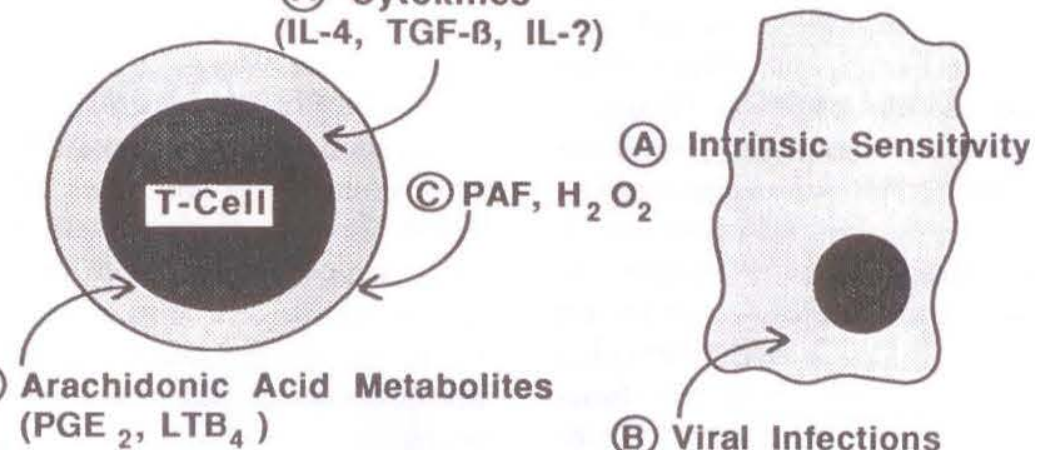

Figure 3) Three hypothesized immune abnormalities in inflammatory bowel disease. $1 \mathrm{~T}$ cells may be more sensitive to known triggers of cytokine production. $2 \mathrm{~T}$ cells may be less sensitive to down-regulatory signals present in the mucosal compartment. 3 The target cell may be more sensitive to individual effects or combinations of cytokines. LPS Lipopolysaccharides; IL Interleukin; TGF Transforming growth factor; PAF Platelet-activating factor; PGE 2 Prostaglandin $E_{2} ; L_{T} B_{4}$ Leukotriene $B_{4}$

on cellular metabolism. This has been demonstrated most recently in the destruction of virally infected human targets by lymphokines released from cytotoxic T cells (61) and the enhanced lywis of fibroblasts infected with adenovirus by TNF-alpha (62). Thus, villous cell atrophy and crypt cell hyperplasia seen following polyclonal $\mathrm{T}$ cell activation in fetal jejunum organ culture (53) or Crohn's disease epithelial changes could reflect differing responses of the two cell types to released cytokines. The present study suggests that human mucosal T cells may be involved in indirect cytokinemediated damage to colonic mucosa during local immune reactions and could play a role in the mucosal damage seen in IBD.

Figure 3 portrays several potential abnormalities in cytotoxic cytokine

\section{REFERENCES}

1. Perlman $P$, Broberger $O$. In vitro studies of ulcerative colitis. II. Cytotoxic action of white blood cells from patients on human fetal colon. J Exp Med 1963;117:717-33.

2. Watson DW, Quigley JA, Bolt RH. Effects of lymphocytes from patients with ulcerative colitis on human adult colon epithelial cells. Gastroenterology 1966;51:985-93.

3. Shorter RG, Cardoza M, Huizinga KA, production, release and function which, although they have yet to be tested in human disease and animal models, could be operative in the chronic damage seen in IBD. Activated $\mathrm{T}$ cells within the mucosa of patients with IBD could be more sensitive to triggers of cytokine production and release. Abnormalities in down-regulation of the immune system may be present in patients with IBD. Insufficiency or total lack of down-regulation could be due to a loss in sensitivity of activated $\mathrm{T}$ cells to known downregulatory signals present in inflammation, ie, cytokines, arachidonic acid metabolites and other inflammatory molecules. Finally, the IBD epithelial cells could be more sensitive to cytokines or combinations either because of intrinsic alteration to their effects or by greater susceptibility to

ReMine SG, Spencer RJ. Further studies of in vitro cytotoxicity of lymphocytes for colonic epithelial cells. Gastroenterology 1969;57:30-5.

4. Shorter RG, Cardoz M, Spencer RJ, Huizinga KA. Further studies of in vitro cytotoxicity of lymphocytes from patients with ulcerative and granulomatous colitis for allogeneic colonic epithelial cells, including the effects of colectomy. Gastroenterology 1969;56:304-9. certain stimuli such as viral infections, which induce such increased sen. sitivity.

To clearly address these issues, chronic spontaneous animal models of induced IBD need to be discovered, and long term epithelial cultures from patients with Crohn's disease and ul. cerative colitis need to be established. Once these systems are available, further inroads can be made to determine the role of both direct and indirect im. mune cytotoxicity in tissue damage in IBD.

ACKNOWLEDGEMENTS: The authors are supported by the UCLA Inflammatory Bowel Disease Center (USPHS grants AM 36200, Al 15332, CA 37205 and DK 40057) and by the National Foundation for lleitis and Colitis.

5. Shorter RG, Cardoza MR, ReMine SG, Spencer RJ, Huizinga KA.

Modification of in vitro cytotoxicity of lymphocytes from patients with chronic ulcerative colitis or chronic granulomatous colitis for allogenic colon epithelial cells. Gastroenterology 1970;58:692-8.

6. Shorter RG, Huizinga KA, Spencer RJ, Aas J, Guy SK. Inflammatory bowel disease. Cytophilic antibody and the cytotoxicity of lymphocytes for colonic 
cells in vitro. Dig Dis Sci 1971;16:673. 80.

7. Shorter RG, Huizinga KA, Spencer RJ. A working hypothesis for the etiology and pathogenesis of nonspecific inflammatory bowel disease. Dig Dis Sci 1972;17:1024-32.

8. Stobo JD, Tomasi TB, Huizinga KA, Spencer RJ, Shorter 'RG. In vitro studies of inflammatory bowel disease: Surface receptors of the mononuclear cells required to lyse allogeneic colonic epithelial cells. Gastroenterology 1976;70:171-6.

9. Watson DW, Bolt RJ. Immune mechanisms in ulcerative colitis. In: Glass GBJ, ed. Progress in Gastroenterology, Vol 1. New York: Grune and Stratton, 1968:391-411.

10. Kemler BJ, Alpert JE. Inflammatory bowel disease: A study of cell-mediated cytotoxicity for isolated human colonic epithelial cells. Gut 1980;21:353-9.

11. Shorter RG, McGill DB, Bahn RC. Cytotoxicity of mononuclear cells for autologous colonic epithelial cells in colonic diseases. Gastroenterology 1984;86:13-22.

12. Shanahan F. Inflammatory bowel disease. In: Targan SR, moderator. Immunology of Intestinal Diseases. Ann Intern Med 1987;106:853-70.

13. Aronson RA, Cook SL, Roche JK. Sensitization to epithelial antigens in chronic pucosal inflammatory disease. 1. Purification characterization and immune reactivity of murine epithelial cell-associated components (ECAC). J Immunol 1983;131:2796-804.

14. Roche JK, Fiocchi C, Youngman K. Sensitization to epithelial antigens in chronic mucosal inflammatory disease. Characterization of human intestinal mucosa-derived mononuclear cells reactive with purified epithelial cellassociated components in vitro. J Clin Invest 1985;75:522-30.

15. Roche JK, Cook SR, Day ED. Cellular cytotoxicity and gastrointestinal inflammation in inbred rats: Induction with gut organ-specific antigens. Immunology 1981;44:489-97.

16. Zinkernagel RM, Doherty PC. H-2 compatibility requirement for $\mathrm{T}$ cell mediated lysis of target cells infected with lymphocytic choriomeningitis virus. Different cytotoxic T cell specificities are associated with structures coded in H-2K or H-2D.J Exp Med 1975;141:1427-36.

17. Acuto O, Reinherz EL. The human T cell receptor. Structure and function. NEngl J Med 1985;312:1100-11.

18. Clancy R, Pucci A. Absence of K cells in the human gut mucosa. Gut 1978;19:273-6.

19. Fiocchi C, Battisto JR, Farmer RG. Gut mucosal lymphocytes in inflam- matory bowel disease. Isolation and preliminary characterization. Dig Dis Sci 1979;24:705-17.

20. Chiba M, Shorter RG, Thayer WR, Bartnik W, ReMine S. K-cell activity in lamina propria lymphocytes from the human colon. Dig Dis Sci 1979;24:817-22.

21. MacDermott RP, Franklin GO, Jenkins KM, Kodner IJ, Nash GS, Weinrieb IJ. Human intestinal mononuclear cells. 1. Investigation of antibody-dependent, lectin-induced, and spontaneous cell-mediated cytotoxic capabilities. Gastroenterology 1980;78:47-56.

22. Bland PW, Britton DC, Richens ER, Pledger JV. Peripheral, mucosal, and tumor infiltrating components of cellular immunity in cancer of the large bowel. Gut 1981;22:744-51.

23. Bland PW, Richens ER, Britton DC, Lloyd JV. Isolation and purification of human large bowel mucosal lymphoid cells: Effect of separation technique on functional characteristics. Gut 1979;20:1037-46.

24. Chiba M, Bartnik W, ReMine SG, Thayer WR, Shorter RG. Human colonic intraepithelial and lamina propria lymphocytes: Cytotoxicity in vitro and the potential effects of isolation method on their functional properties. Gut 1981;22:177-86.

25. Gibson PR, Hermanowicz A, Verhaar HJJ, Ferguson DJP, Lopez Bernal A, Jewell DP. Isolation of intestinal mononuclear cells: Factors released which may affect lymphocyte viability and function. Gut 1985;26:60-8.

26. Auer IO, Zeimer E, Sommer H. Immune status in Crohn's disease. V. Decreased in vitro natural killer cell activity in peripheral blood. Clin Exp Immunol 1980;42:41-9.

27. Beeken WL, MacPherson BR, Gundel RM, St Andre-Ukena S, Wood SG, Sylvester DL. Depressed spontaneous cell-mediated cytotoxicity in Crohn's disease. Clin Exp Immunol 1983;51:351-8.

28. Ginsburg CH, Dambrauskas JT, Ault KA, Falchuk ZM. Impaired natural killer cell activity in patients with inflammatory bowel disease: Evidence for a quantitative defect. Gastroenterology 1983;85:846-51.

29. Gibson PR, Verhaar HJJ, Sellby WS, Jewell DP. The mononuclear cells of human mesenteric blood, intestinal mucosa and mesenteric lymph nodes: Compartmentalization of NK cells. Clin Exp Immunol 1984;56:445-52.

30. Fiocchi C, Tubbs RR, Youngman KR. Human intestinal mucosal mononuclear cells exhibit lymphokine-activated cell activity. Gastroenterology $1985 ; 44: 625-37$.
31. Shanahan F, Brogan M, Targan S. Human mucosal cytotoxic effector cells. Gastroenterology 1987;92:1951-7.

32. Falchuk ZM, Barnhard E, Machado I. Human colonic mononuclear cells: Studies of cytotoxic function. Gut 1981;22:290-4.

33. Targan SR, Britvan L, Kendall R, Vimadalal S, Soll A. Isolation of spontaneous and interferon inducible natural killer like cells from human colonic mucosa: Lysis of lymphoid and autologous epithelial target cells. Clin Exp Immunol 1983;54:14-22.

34. Beeken WL, Gundel M, St AndreUkena S, McAuliffe T. In vitro cellular cytotoxicity for a human colon cancer cell line by mucosal mononuclear cells of patients with colon cancer and other disorders. Cancer 1985;55:1024-9.

35. Kett K, Rognum TO, Brandtzaeg P. Mucosal subclass distribution of immunoglobulin G-producing cells is different in ulcerative colitis and Crohn's disease of the colon. Gastroenterology 1987;83:919-24.

36. Gibson PR. NK cells, IBD and cancer. Gastroenterology 1986;90:1314-5.

37. Hogan PG, Hapel AJ, Doe WF. Lymphokine activated and natural killer cell activity in human intestinal mucosa. J Immunol 1985;135:1731-8.

38. Rosenberg SA, Lotze MT, Muul LM, et al. A progress report on the treatment of 157 patients with advanced cancer using lymphokine activated killer cells and interleukin-2 of high dose alone. N Engl ] Med 1987;316:889-97.

39. Itoh K, Tilden AB, Kumagai K, Balch CM. Leu $11+$ lymphocytes with natural killer (NK) activity are precursors of recombinant interleukin-2 (rIL2)-induced activated killer (AK) cells. J Immunol 1985;134:802-7.

40. Phillips JH, Lanier LL. Dissection of the lymphokine activated killer phenomenon. Relative contribution of peripheral blood natural killer cells and T lymphocytes to cytolysis. J Exp Med 1986;164:814-25.

41. Kasugami K, Youngman KR, West $\mathrm{GA}$, Fiocchi C. Intestinal immune reactivity to interleukin 2 differs among Crohn's disease, ulcerative colitis, and controls. Gastroenterology 1989;97:1-9.

42. Fiocchi C, Hilfiker ML, Youngman KR, Doerder NC, Finke JH. Interleukin-2 activity of human intestinal mucosal mononuclear cells. Decreased levels of inflammatory bowel disease. Gastroenterology 1984;86:734-42.

43. MacDermott RP, Bragdon M], Kodner IJ, Bertovich MJ. Deficient cellmediated cytotoxicity and hyporesponsiveness to interferon and mitogenic 
lectin activation by inflammatory bowel disease peripheral blood and intestinal mononuclear cells. Gastroenterology 1986;90:6-11.

44. Shanahan F, Brogan M, Newman W, Targan S. K562 killing by K and KL-2 responsive $\mathrm{NK}$ and $\mathrm{T}$ cells involves different post binding trigger mechanisms. J Immunol 1986;137:723-6.

45. Weiss A, Imboded J, Hardy K, Manger B, Terhorst C, Stobo J. The role of the $\mathrm{T} 3$ /antigen receptor complex in T-cell activation. Annu Rev Immunol 1986;4:593-619.

46. Phillips JH, Lanier LL. Lectin-dependent and anti-CD3 induced cytotoxicity are preferentially mediated by peripheral blood cytotoxic T lymphocytes expressing Leu 7 antigen. J Immunol 1986;136:1579-85.

47. Shanahan F, Deem R, Nayersina R, Leman B, Targan S. Human mucosal T cell cytotoxicity. Gastroenterology 1988;94:960-7.

48. Shanahan F, Leman B, Deem R, Niederlehner A, Brogan M, Targan S. Enhanced peripheral blood T cell cytotoxicity in inflammatory bowel disease. Gastroenterology 1989;9:55-64.

49. Duerr R, Deem R, Landers C, Niederlehner A, Targan S, Shanahan F. Analysis of elevated mucosal and peripheral cytotoxic $\mathrm{T}$ cell function in IBD. Gastroenterology 1989;96:A132.
50. Pallone $\mathrm{F}$, Fais $\mathrm{S}$, Squarcia $\mathrm{O}$, Biancone L, Boirivant M. Activation of peripheral blood and intestinal lamina propria lymphocytes in Crohn's disease. In vivo state activation and in vitro response to stimulation as defined by the expression of early activation antigens. Gut 1987;28:745-53.

51. Kagnoff NM, Austin RK, Hubert JJ, Benardin JE, Kadarda DD. Celiac sprue: Correlation with murine $\mathrm{T}$ cell responses to wheat gliadin components. J Exp Med 1984;160:1544-57.

52. MacDonald TT, Spencer J. Evidence that activated mucosal $\mathrm{T}$ cells play role in the pathogenesis of enteropathy in human small intestine. J Exp Med $1988 ; 167: 1341-9$.

53. Entrican JH, Busuttil A, Ferguson A. Are the focal microscopic jejunal lesions in Crohn's disease produced by a T cell mediated immune response? Scand J Gastroenterol 1987;22:1071-5.

54. Selby WS, Janossy G, Mason DY, Jewell DP. Expression of HLA-DR antigens by colonic epithelium in inflammatory bowel disease. Clin Exp Immunol 1983;53:614-8.

55. McDonald GB, Jewell DP. Class H antigen (HLA-DR) expression by intestinal epithelial cells in inflammatory bowel diseases of the colon. J Clin Pathol 1987;40:312-7.

56. Thompson CB, Lindsten T, Ledbetter
JA, et al. CD28 activation pathway regulates production of multiple $T$-cell. derived lymphokines/cytokines. Proc Natl Acad Sci USA 1989;86:1333.

57. Sung SSSJ, Bjorndahl JM, Wang CY, Kao HT, Fu SM. Production of tumor necrosis factor/cachectin by human T cell lines and peripheral blood $\mathrm{T}$ lymphocytes stimulated by phorbol myristate acetate and anti-CD3 antibody. J Exp Med 1988;167:937.

58. Campbell IL, Iscaro A, Harrison LC. IFN-gamma and tumor necrosis factoralpha cytotoxicity to murine islet of Langerhans. J Immunol 1988;141:2325-9.

59. Hofman FM, Hinton DR, Johnson K, Merrill JE. Tumor necrosis factor identified in multiple sclerosis brain. J Exp Med 1989;170:607-12.

60. Pay CV, Kenmotsu N, Schoon RA, Leibson PH. Tumor necrosis factor and lymphotoxin secretion by human natural killer cells leads to antiviral cytotoxicity. J Immunol 1988;141:1989-95.

61. Rosenblum MG, Donato NJ. Tumour necrosis factor alpha: A multifaceted peptide hormone. Crit Rev Immunol 1989;9:21-44.

62. Duerksen-Hughes P, Wold WSM, Gooding LR. Adenovirus ElA renders infected cells sensitive to cytolysis by tumor necrosis factor. J Immunol 1989;143:4193-200. 


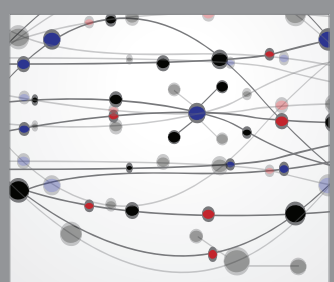

The Scientific World Journal
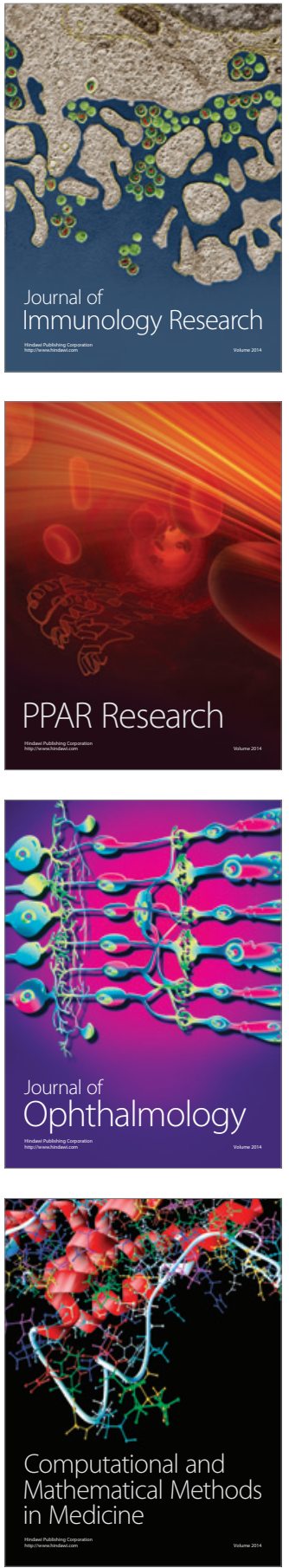

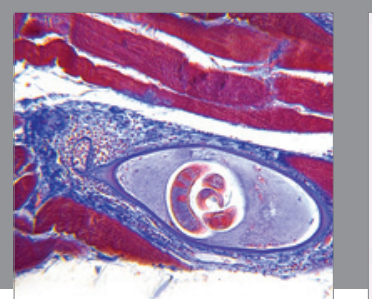

Gastroenterology Research and Practice

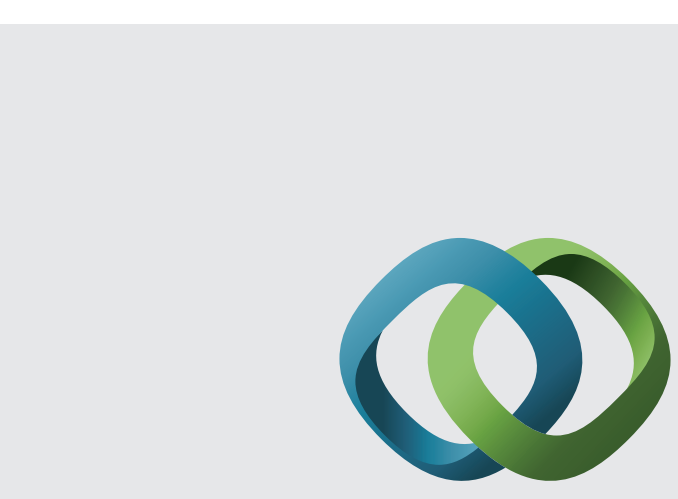

\section{Hindawi}

Submit your manuscripts at

http://www.hindawi.com
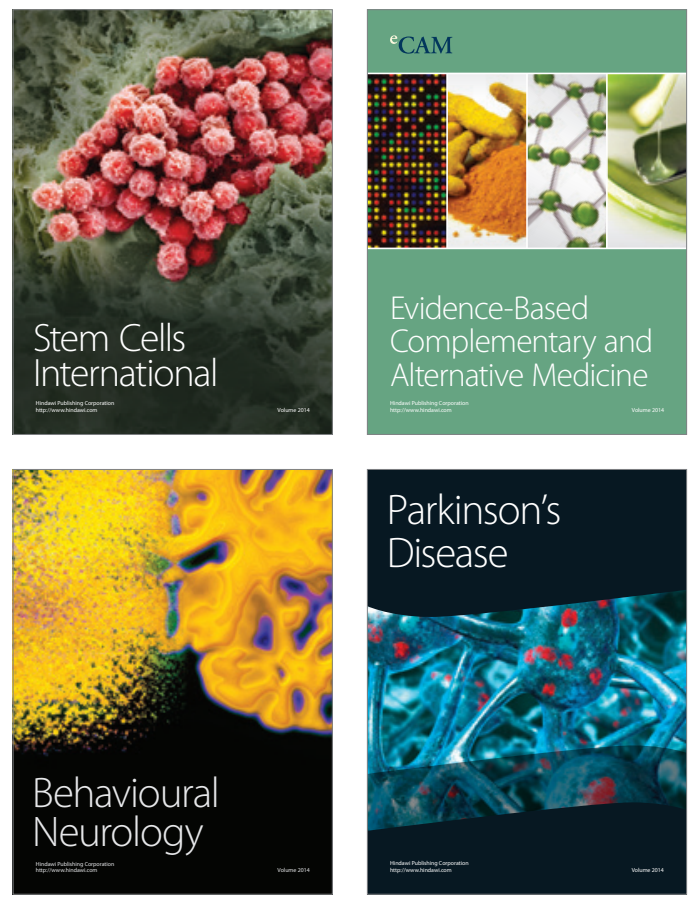
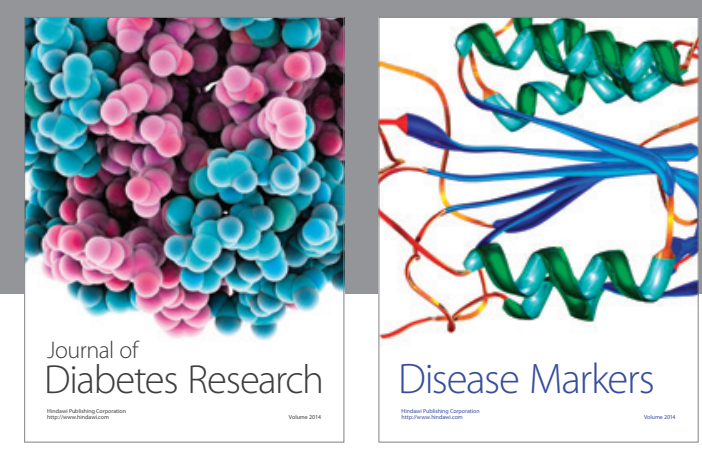

Disease Markers
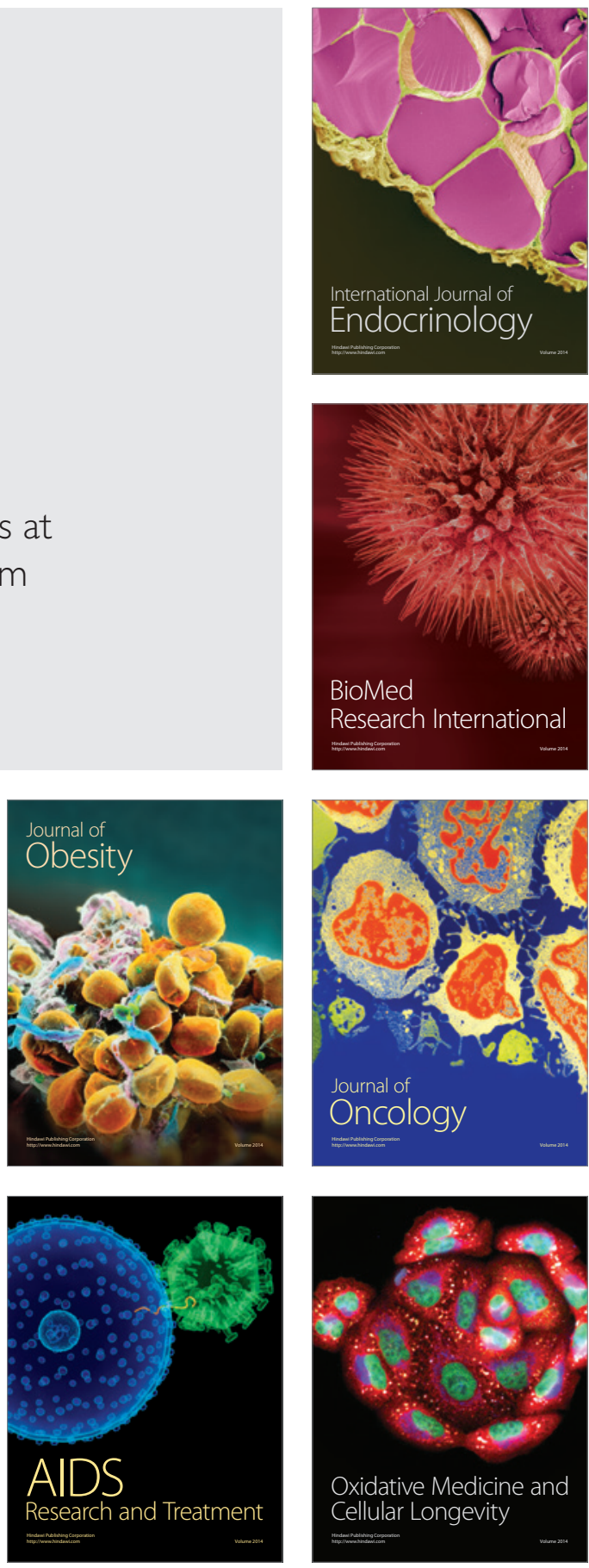